\title{
Kematangan Emosi Ditinjau dari Pola Asuh Otoriter Orang Tua pada Siswa SMP Talitakum Medan
}

\author{
Vidi Marsha Lorenza Silitonga, Fransiscus Josua, Rianda Elvinawanty \\ Fakultas Psikologi, Universitas Prima Indonesia, Medan, Indonesia \\ Email: vdmarsha97@gmail.com, franztheo19@gmail.com, rianda@unprimdn.ac.id
}

\begin{abstract}
This study aims to know the relationship between the authoritarian parenting with emotional maturity. The hypothesis in this study is there is a negative relationship between authoritarian parenting with emotional maturity, in assumption that the higher authoritarian parenting, then the higher emotional maturity and the lower authoritarian parenting, then the lower the emotional maturity itself. The subjects that used in this study are students at the SMP Talitakum Medan, in which the population consists of 98 students. Data obtained from the scale to measure authoritarian parenting and emotional maturity. The calculation of the data began by doing a test prerequisite analysis (the test of assumptions) that consists of a test of normality and a test of linearity. The data analysis in this study uses the Product Moment Correlation with SPSS 21 for Windows. The results of analysis showed the correlation coefficient at - 0,569 of the significance $0.000(\mathrm{p}<0.05)$. This shows there is a negative relationship between authoritarian parenting with emotional maturity. The results of this study indicate that the variable of emotional maturity can be predicted by authoritarian parenting at 32.4 percent and 67.6 percent of the rest are influenced by other factors which not examined in this study. Based on the results of this study, the hypothesis is accepted that there is a negative relationship between authoritarian parenting with emotional maturity.
\end{abstract}

Keywords : Authoritarian Parenting, Emotional Maturity.

\begin{abstract}
Abstrak
Penelitian ini bertujuan untuk mengetahui hubungan antara pola asuh otoriter dengan kematangan emosi. Hipotesis yang diajukan dalam penelitian ini adalah ada hubungan negatif antara pola asuh otoriter dengan kematangan emosi, dengan asumsi semakin tinggi pola asuh otoriter, maka semakin tinggi kematangan emosi dan sebaliknya semakin rendah pola asuh otoriter, maka semakin rendah kematangan emosi. Subjek penelitian yang digunakan dalam penelitian ini adalah peserta didik di siswa SMP Talitakum Medan, sebanyak 98 orang. Data diperoleh dari skala untuk mengukur pola asuh otoriter dan kematangan emosi. Perhitungan dilakukan dengan melakukan uji prasyarat analisis (uji asumsi) yang terdiri dari uji normalitas dan uji linearitas. Analisis data yang digunakan adalah menggunakan korelasi Product Moment melalui bantuan SPSS 21 for Windows. Hasil analisis data menunjukkan koefisien korelasi sebesar - 0,569 dan nilai signifikansi sebesar $0.000(\mathrm{p}<0.05)$. Ini menunjukkan ada hubungan negatif antara pola asuh otoriter dengan kematangan emosi. Hasil penelitian ini menunjukkan bahwa sumbangan yang diberikan variabel pola asuh otoriter terhadap kematangan emosi sebesar 32,4 persen. Selebihnya 67,6 persen dipengaruhi oleh faktor lain, seperti kelekatan aman, jenis kelamin, usia, layanan bimbingan kelompok, pelatihan asertif dan layanan penguasaan konten dengan teknik bermain (games).
\end{abstract}

Kata kunci: Pola Asuh Otoriter, Kematangan Emosi

\section{Pendahuluan}

Remaja adalah masa yang pasti dilalui oleh setiap manusia. Pada masa ini, individu akan mempelajari dan melalui berbagai hal dalam menghadapi masa kedewasaannya, seperti harus belajar untuk beradaptasi dengan berbagai perubahan pada dirinya baik secara fisik maupun psikis. Remaja atau adolescence berasal dari Bahasa Latin adolescere yang artinya "tumbuh atau tumbuh untuk mencapai kematangan". Istilah adolescence sesungguhnya memiliki arti yang luas, mencakup kematangan mental, emosional, sosial dan fisik [5]. Pandangan ini didukung oleh Piaget (dalam [5]) yang mengatakan bahwa secara psikologis, remaja adalah suatu usia di mana individu menjadi terintegrasi ke dalam masyarakat dewasa, usia di mana anak tidak merasa bahwa dirinya berada di bawah tingkat orang yang lebih tua

Diterima Redaksi : 15-09-2020 | Selesai Revisi : 22-04-2021 | Diterbitkan Online : 28-04-2021 
melainkan merasa sama, atau paling tidak sejajar. Santrock [11] menyatakan bahwa remaja masih belum mampu menguasai dan memfungsikan secara maksimal fungsi fisik maupun psikisnya.

Santrock [11] menganggap masa remaja sebagai periode "badai dan tekanan". Suatu masa dimana ketegangan emosi meninggi sebagai akibat dari perubahan fisik dan hormon. Remaja dapat merasa seolah sedang di puncak bumi, lalu merasa sedang berada di dasar kesedihan yang sangat mendalam dalam waktu yang singkat. Adapun meningginya emosi terutama karena para remaja berada di bawah tekanan sosial dan menghadapi kondisi baru, sedangkan selama masa kanak-kanak ia kurang mempersiapkan diri untuk menghadapi keadaan-keadaan itu. Ketika berada dalam keadaan emosi yang memuncak, remaja biasanya cenderung didominasi oleh emosinya saat akan mengambil keputusan

Tindakan remaja yang didominasi emosi semata dapat terlihat pada kasus yang terjadi di Medan pada Januari 2020 silam. Awalnya, remaja ini terlibat dalam aksi tawuran di jalan raya dengan saling melemparkan batu ke pihak lawan. Sampai akhirnya salah seorang remaja tersebut diamankan oleh pihak kepolisian, dan remaja tersebut tampak panik serta mulai menangis ketakutan. Remaja yang terlihat panik tersebut memohon kepada petugas agar tidak dibawa ke kantor polisi dengan alasan bahwa ibunya memiliki kondisi jantung yang lemah. Ia mengungkap bahwa jika dirinya ditahan, maka akan mempengaruhi kesehatan ibunya. Lalu sesaat kemudian, remaja itu kembali berbalik menantang wartawan yang sedang meliput kejadian tersebut. [15]

Selain kasus di atas, peneliti juga menemukan perilaku emosional pada siswa SMP Talitakum Medan. Berdasarkan hasil observasi dan wawancara yang telah dilakukan, ditemukan bahwa banyak siswa yang sering bertengkar dengan siswa lainnya. Perselisihan tersebut sering disebabkan oleh hal-hal sederhana yang seharusnya dapat diselesaikan, seperti saling mengejek. Ejekan yang dilontarkan oleh A awalnya hanya ditanggapi santai oleh B sebagai suatu candaan, namun A tidak berhenti mengejek sehingga akhirnya membuat B marah dan memukul A. Perkelahian pun terus berlanjut hingga B mendorong A ke arah jendela kelas dan membuat pecahnya kaca jendela tersebut. Akibatnya, siswa B mengalami luka sobek pada lengannya hingga harus dijahit sebanyak tujuh jahitan sementara siswa A tidak mengalami luka berat. Kasus lainnya yang sering terjadi adalah banyaknya siswa yang menggunakan bahasa-bahasa kasar dan tidak senonoh saat berbicara dengan temannya, dan melawan perkataan guru sekolahnya. Adapula siswa yang merasa malu dan selalu berusaha untuk tidak terlibat dengan teman-temannya. Penuturan beberapa teman sekelasnya menyatakan bahwa siswa tersebut merasa rendah diri (minder) karena tidak memiliki smartphone, seperti teman sekelasnya. Ia sering menyendiri dan mudah sekali menangis (memiliki perasaan yang sensitif).

Berdasarkan penjelasan kasus di atas, remaja-remaja tersebut memiliki tindakan yang emosional. Tindakan emosional tersebut bersifat sesaat dan muncul secara impulsif. Ini menunjukkan bahwa, para remaja sedang mengalami suatu kondisi di mana mereka masih belum mampu berpikir lebih jauh sebelum bertindak, dan memiliki pandangan atau pemahaman yang sempit. Ketidakmampuan ini memiliki arti para remaja tersebut belum memiliki kematangan emosi yang memadai.

Menurut Sudarsono [12], kematangan emosi adalah kedewasaan secara emosi, tidak terpengaruh kondisi kekanak-kanakan atau sudah dewasa secara total. Selain itu, Hurlock [5] menyatakan bahwa kematangan emosi adalah bahwa individu menilai situasi secara kritis terlebih dahulu sebelum bereaksi secara emosional, tidak lagi bereaksi tanpa berpikir sebelumnya seperti anak-anak atau orang yang tidak matang.

Hurlock [5] mengatakan bahwa secara intensif kematangan emosi mulai terbentuk sejak bayi, kanakkanak, dan remaja. Kematangan emosi sangat diperlukan untuk pendewasaan diri. Individu yang telah mencapai kematangan dalam hal emosi dapat diidentifikasikan sebagai individu yang dapat menilai situasi secara kritis terlebih dahulu sebelum bertindak, tidak lagi bereaksi tanpa berpikir sebelumnya seperti anak-anak atau orang yang tidak matang, mampu mengendalikan emosinya secara baik, mengetahui cara dan waktu yang tepat untuk mengungkapkan emosi.

Salah satu faktor yang mempengaruhi kematangan emosi adalah pola asuh otoriter. Berns [3] pola asuh otoriter berarti pola asuh yang mencoba untuk membentuk, mengontrol, dan mengevaluasi bahwa perilaku dan sikap anak sesuai dengan standar perilaku, biasanya standar mutlak, teologis termotivasi 
dan dirumuskan oleh otoritas yang lebih tinggi. Pola asuh ini menghargai ketaatan sebagai suatu kebajikan dan nikmat hukuman, dan tindakan yang kuat untuk mengekang diri, di mana tindakan anak atau konflik keyakinan dengan apa yang dia pikir adalah perilaku yang benar. Pola asuh ini juga menanamkan nilai-nilai penting seperti menghormati otoritas, menghormati kerja, dan rasa hormat untuk pelestarian tatanan dan struktur tradisional. Sejalan dengan ahli di atas, Baumrind (dalam [11]) menyatakan bahwa pola asuh otoriter adalah gaya yang membatasi dan menghukum dimana orang tua menasehati remaja mengikuti arahan dan menghormati kerja dan usaha. Orang tua otoriter membatasi dan mengendalikan perasaan remaja dan memungkinkan pertukaran verbal sedikit. Pola asuh otoriter dikaitkan dengan perilaku sosial remaja yang tidak kompeten. Remaja orang tua otoriter sering khawatir dengan perbandingan sosial, gagal memulai aktivitas, dan memiliki kemampuan komunikasi yang buruk.

Berdasarkan penelitian yang dilakukan oleh Noviata [9] pada remaja SMA di Surabaya, diketahui bahwa ada pengaruh pola asuh otoriter terhadap kematangan emosi pada remaja. Orang tua yang melakukan pengasuhan otoriter tidak mengizinkan anaknya untuk mengungkapkan pendapatnya, sehingga menjadikan anak kurang dapat mengontrol emosinya, anak cenderung tertutup dan jika anak mempunyai konflik, anak lebih memilih untuk menyimpannya dalam hati dan berusaha menyelesaikannya sendiri. Hal ini menyebabkan anak sulit mengontrol emosi serta menjalin hubungan yang baik dengan lingkungan sekitarnya. Adapun terdapat pengaruh negatif antara pola asuh otoriter dengan kematangan emosi, yakni semakin tinggi tingkat pola asuh otoriter maka semakin rendah tingkat kematangan emosi. Sebaliknya semakin rendah tingkat pola asuh otoriter, maka semakin tinggi tingkat kematangan emosi.

Adanya pengaruh antara pola asuh orang tua dengan kematangan emosi semakin dipertegas oleh penelitian yang dilakukan Lumenta, dkk., [7] pada siswa SMAN 1 Sinonsayang. Hasil penelitian ini mengungkap bahwa pola asuh orang tua memiliki pengaruh besar bagi pertumbuhan kepribadian yang beremosi stabil, bertanggung jawab, dan mampu menjalin hubungan interpersonal yang positif. Artinya pola asuh orang tua berpengaruh bagi kematangan emosi remaja. Orang tua merupakan lembaga pertama dan utama dalam kehidupan anak, tempat belajar dan menyatakan diri sebagai makhluk sosial. Melalui pola interaksi di dalam keluarga akan menentukan pola perilaku anak terhadap orang lain di dalam lingkungannya. Orang tua yang memiliki pola pengasuhan yang terlalu mengekang dan tidak memberikan kesempatan bagi anak untuk mengambil keputusan dalam berbagai proses perkembangannya, cenderung membuat anak tumbuh memiliki temperamen yang buruk. Hal tersebut menunjukkan bahwa ada pengaruh negatif antara pola asuh orang tua terhadap kematangan emosi seorang anak.

Dari pemaparan di atas, peneliti ingin melakukan suatu penelitian yang berjudul, "Kematangan Emosi ditinjau dari Pola Asuh Otoriter pada Siswa SMP Talitakum".

\section{Metode Penelitian}

Metode penelitian yang digunakan untuk mendapatkan data yang diperlukan dalam penelitian ini adalah metode skala [2]. Adapun jenis skala yang digunakan dalam penelitian ini adalah skala Likert. Kriteria penilaian aitem favourable berdasarkan skala Likert adalah nilai satu (1) untuk jawaban Sangat Tidak Setuju (STS), nilai dua (2) untuk jawaban Tidak Setuju (TS), nilai tiga (3) untuk jawaban Setuju (S), dan nilai empat (4) untuk jawaban Sangat Setuju (SS). Sedangkan kriteria penilaian untuk aitem unfavourable adalah nilai satu (1) untuk jawaban Sangat Setuju (SS), nilai dua (2) untuk jawaban Setuju (S), nilai tiga (3) untuk jawaban Tidak Setuju (TS), dan nilai empat (4) untuk jawaban Sangat Tidak Setuju (STS) (Suryabrata, 2000). Teknik pengumpulan data dalam penelitian ini dilakukan dengan cara pembagian skala.

Penelitian ini menggunakan 2 skala, yaitu skala Kematangan Emosi dan skala Pola Asuh Otoriter. Untuk skala Kematangan Emosi, skala ini dibuat berdasarkan karakteristik kematangan emosi yang diungkapkan oleh Walgito [14] yaitu menerima baik keadaan dirinya, tidak bersifat impulsif, mengontrol emosinya dengan baik, berpikir secara objektif dan mempunyai tanggung jawab yang baik. Jumlah aitem skala adalah 30 aitem yang memiliki nilai reliabilitas $\alpha$ sebesar 0,938 dan nilai validitas 
dengan rentang nilai 0,356 hingga 0,908. Sedangkan untuk skala Pola Asuh Otoriter, skala ini dibuat berdasarkan sub-scale pola asuh otoriter dari pengukuran pola asuh orang tua yang dilakukan oleh Robinson, dkk., [10] dengan menggunakan The Parenting Styles and Dimensions Questionnaire (PSDQ) yang terdiri dari empat faktor yaitu verbal hostility, corporal punishment, nonreasoning/punitive strategies, dan directiveness. Skala ini berjumlah 30 aitem dan nilai reliabilitas $\alpha$ sebesar 0,93 serta rentang nilai validitas sebesar 0,302 sampai 0,764 .

Penelitian ini menggunakan teknik sampling jenuh dimana sampel dalam penelitian ini adalah seluruh siswa SMP Sekolah Talitakum yang berjumlah 98 orang.

Analisis data menggunakan bantuan aplikasi SPSS Statistics 21 for Windows.

\section{Hasil dan Pembahasan}

Seluruh aitem yang akan digunakan dalam penelitian adalah 60 aitem. Dua skala kematangan emosi dan skala pola asuh otoriter digabung dalam satu set eksemplar, yang termasuk di dalamnya adalah petunjuk pengisian skala dan identitas subjek.

Selanjutnya dilakukan pemberian nilai dari setiap aitem dalam skala. Pemberian nilai dilakukan dengan melihat kembali bobot dari setiap aitem dan kemudian memasukkan data dengan bantuan Microsoft Excel yang kemudian akan disalin ke SPSS untuk dilakukan analisis data untuk mengetahui hubungan antara kedua variabel.

\subsection{Hasil}

\subsubsection{Deskripsi Hasil Penelitian}

\section{a. Skala Kematangan Emosi}

Skala kematangan emosi terdiri dari 30 aitem dengan skor aitemnya yang bergerak dari empat pilihan jawaban dengan skor satu sampai empat. Rentang minimum dan maksimumnya adalah 30x1 sampai $30 x 4$, yaitu 30 sampai 120 dengan mean hipotetiknya $(120+30): 2=75$. Standar deviasi hipotetik dalam penelitian ini adalah $(120-30): 6=15$. Dari skala kematangan emosi yang diisi subjek, maka diperoleh mean empirik sebesar 91.36 dengan standar deviasi 10,476. Perbandingan data empirik dan data hipotetik dapat dilihat pada Tabel 1 dibawah.

Tabel 1.

Perbandingan Data Empirik dan Data Hipotetik Kematangan emosi

\begin{tabular}{|c|c|c|c|c|c|c|c|c|}
\hline \multirow{2}{*}{ Variabel } & \multicolumn{3}{|c|}{ Empirik } & \multirow{3}{*}{ SD } & \multicolumn{3}{c|}{ Hipotetik } & \multirow{2}{*}{ SD } \\
\cline { 2 - 3 } & Min & Max & Mean & & Min & Max & Mean & \\
\hline Kematangan emosi & 60 & 113 & 91,36 & 10,476 & 30 & 120 & 75 & 15 \\
\hline
\end{tabular}

Apabila mean empirik > mean hipotetik maka hasil penelitian yang diperoleh akan dinyatakan tinggi, dan sebaliknya jika mean empirik < mean hipotetik maka hasil penelitian akan dinyatakan rendah. Hasil analisis untuk skala kematangan emosi diperoleh mean empirik > mean hipotetik yaitu 91,36>75, maka dapat disimpulkan bahwa kematangan emosi subjek penelitian lebih tinggi daripada populasi pada umumnya.

Selanjutnya subjek akan dibagi ke dalam tiga kategori kematangan emosi, yaitu kematangan emosi rendah, sedang dan tinggi. Pengkategorian kematangan emosi dengan membagi distribusi normal ke dalam tiga bagian standar deviasi.

$$
\mathrm{x}<(\mu-1,0 \sigma) \quad \text { kategori rendah }
$$




$$
\begin{aligned}
& (\mu-1,0 \sigma) \leq \mathrm{x}<(\mu+1,0 \sigma) \quad \text { kategori sedang } \\
& \mathrm{x} \geq(\mu+1,0 \sigma) \quad \text { kategori tinggi }
\end{aligned}
$$

Standar deviasi hipotetik dalam penelitian ini adalah $\sigma=(120-30): 6=15$ dan mean hipotetiknya adalah $(120+30): 2=75$. Dari perhitungan di atas dapat dibuat perhitungannya berdasarkan rumus yang telah diuraikan di atas, maka diperoleh $\mathrm{x}<(75-15)=\mathrm{x}<60,(75-15) \leq \mathrm{x}<(75+15)=60 \leq \mathrm{x}$ $<90$, dan $x \geq(75+15)=x \geq 90$. Dari perhitungan di atas, dapat dibuat kategorisasi pada Tabel berikut ini.

Tabel 2.

Kategorisasi Kematangan emosi

\begin{tabular}{|c|c|c|c|c|}
\hline Variabel & Rentang Nilai & Kategori & Jumlah (n) & Persentase \\
\hline \multirow{2}{*}{$\begin{array}{c}\text { Kematangan } \\
\text { emosi }\end{array}$} & $\mathrm{x}<60$ & Rendah & 0 & $0 \%$ \\
\cline { 2 - 5 } & $60 \leq \mathrm{x}<90$ & Sedang & 39 & $39,80 \%$ \\
\cline { 2 - 5 } & $\mathrm{x} \geq 90$ & Tinggi & 59 & $60,20 \%$ \\
\hline \multicolumn{3}{|c|}{ Jumlah } & $\mathbf{9 8}$ & $\mathbf{1 0 0 \%}$ \\
\hline
\end{tabular}

Dari tabel di atas, dapat disimpulkan bahwa rata-rata subjek penelitian memiliki tingkat kematangan emosi yang tinggi

\section{b. Skala Pola Asuh Otoriter}

Skala pola asuh otoriter terdiri dari 30 aitem dengan skor aitemnya yang bergerak dari empat pilihan jawaban dengan skor satu sampai empat. Rentang minimum dan maksimumnya adalah 30x1 sampai $30 x 4$, yaitu 30 sampai 120 dengan mean hipotetiknya $(120+30): 2=75$. Standar deviasi hipotetik dalam penelitian ini adalah $(120-30): 6=15$. Berdasarkan skala pola asuh otoriter yang diisi subjek, maka diperoleh mean empirik sebesar 87,39 dengan standar deviasi 8,827. Perbandingan data empirik dan data hipotetik dapat dilihat pada Tabel 3.

Tabel 3.

Perbandingan Data Empirik dan Data Hipotetik Pola asuh otoriter

\begin{tabular}{|c|c|c|c|c|c|c|c|c|}
\hline \multirow{2}{*}{ Variabel } & \multicolumn{3}{|c|}{ Empirik } & \multirow{3}{*}{ SD } & \multicolumn{3}{c|}{ Hipotetik } & \multirow{2}{*}{ SD } \\
\cline { 2 - 4 } & Min & Max & Mean & & Min & Max & Mean & \\
\hline Pola Asuh Otoriter & 65 & 108 & 87,39 & 8,827 & 30 & 120 & 75 & 15 \\
\hline
\end{tabular}

Hasil analisis untuk skala pola asuh otoriter diperoleh mean empirik > mean hipotetik yaitu, 87,39> 75, maka dapat disimpulkan bahwa pola asuh otoriter subjek penelitian lebih tinggi daripada populasi pada umumnya.Pengkategorian pola asuh otoriter dengan membagi distribusi normal ke dalam tiga bagian standar deviasi seperti pada skala kematangan emosi. Standar deviasi hipotetik adalah $\sigma=(120-30)$ : $6=15$ dan mean hipotetik adalah $(120+30): 2=75$. Dari perhitungan tersebut, maka diperoleh $\mathrm{x}<(75$ $-15)=\mathrm{x}<60,(75-15) \leq \mathrm{x}<(75+15)=60 \leq \mathrm{x}<90$, dan $\mathrm{x} \geq(75+15)=\mathrm{x} \geq 90$. Dari perhitungan di atas, dapat dibuat kategorisasi pada Tabel 4 berikut ini.

Tabel 4.

\begin{tabular}{|c|c|c|c|c|}
\hline Variabel & Rentang Nilai & Kategori & Jumlah (n) & Persentase \\
\hline \multirow{3}{*}{$\begin{array}{l}\text { Pola asuh } \\
\text { otoriter }\end{array}$} & $\mathrm{x}<60$ & Rendah & 0 & $0 \%$ \\
\hline & $60 \leq x<90$ & Sedang & 60 & $61,22 \%$ \\
\hline & $\mathrm{x} \geq 90$ & Tinggi & 38 & $38.78 \%$ \\
\hline \multicolumn{3}{|c|}{ Jumlah } & 98 & $100 \%$ \\
\hline
\end{tabular}

Kategorisasi Pola asuh otoriter 
Dari nilai pada tabel, dapat disimpulkan bahwa rata-rata subjek penelitian memiliki tingkat pola asuh otoriter yang sedang.

\subsubsection{Hasil Uji Asumsi}

\section{a. Uji Normalitas}

Uji normalitas dilakukan agar dapat mengetahui apakah setiap variabel penelitian telah menyebar secara normal atau tidak. Uji normalitas sebaran menggunakan uji Kolmogorov Smirnov Test. Data dikatakan berdistribusi normal jika $\mathrm{p}>0,05$ [8]. Uji normalitas yang dilakukan terhadap variabel kematangan emosi koefisien KS-Z = 0,735 dengan sig sebesar 0,652 untuk uji 2 (dua) arah, sedangkan penelitian ini memiliki hipotesis satu arah, sehingga yang dipakai adalah uji 1 (satu) ekor / sig 1-tailed sebesar 0,326 ( $p>0,05$ ), yang berarti bahwa data pada variabel kematangan emosi memiliki sebaran atau berdistribusi normal. Uji normalitas pada variabel pola asuh otoriter diperoleh koefisien $\mathrm{KS}-\mathrm{Z}=0,705$ dengan $\mathrm{Sig}$ sebesar 0,705 untuk uji 2 (dua) arah dan sig sebesar 0,3525 untuk uji 1 (satu) arah ( $\mathrm{p}>0,05$ ), yang berarti bahwa data pada variabel pola asuh otoriter sebaran atau berdistribusi normal. Hasil uji normalitas dapat dilihat pada Tabel 5 .

Tabel 5.

Hasil Uji Normalitas

\begin{tabular}{|l|l|l|l|l|l|}
\hline Variabel & SD & KS-Z & Sig. & P & Keterangan \\
\hline Kematangan emosi & 10,476 & 0,735 & 0,326 & $\mathrm{p}>0,05$ & Sebaran normal \\
\hline Pola asuh otoriter & 8.827 & 0,704 & 0,3525 & $\mathrm{p}>0,05$ & Sebaran normal \\
\hline
\end{tabular}

\section{b. Uji Linearitas}

Uji linieritas digunakan untuk mengetahui apakah distribusi data penelitian yaitu variabel kematangan emosi dan pola asuh otoriter memiliki hubungan linier Uji F (Anova). Menurut Sugiyono [13], jika p < 0,05 maka hubungan antara kedua variabel yaitu kematangan emosi dan pola asuh otoriter dikatakan linier. Hasil uji linieritas dapat dilihat pada Tabel 6 berikut.

Tabel 6.

Hasil Uji Linearitas Hubungan

\begin{tabular}{|l|l|l|l|}
\hline Variabel & F & Sig & Keterangan \\
\hline $\begin{array}{l}\text { Kematangan emosi } \\
\text { Pola asuh otoriter }\end{array}$ & 66,495 & 0,000 & Linear \\
\hline
\end{tabular}

\subsubsection{Hasil Pengujian Hipotesis}

Setelah uji asumsi diterima selanjutnya, dilakukan uji hipotesis. Uji Hipotesis yang dilakukan adalah uji korelasi Pearson. Hasil dapat dilihat pada Tabel 7.

Tabel 7.

Korelasi Antara Pola Asuh Otoriter dengan Kematangan Emosi

\begin{tabular}{|c|c|c|}
\hline Analisis & Pearson Correlation & Signifikansi (p) \\
\hline Korelasi & $-0,569$ & 0,000 \\
\hline
\end{tabular}

Berdasarkan hasil analisis korelasi antara pola asuh otoriter dengan kematangan emosi, diperoleh koefisien korelasi Pearson sebesar - 0,569 dengan sig sebesar 0,000 ( $<<0,05)$. Hal ini menunjukkan bahwa adanya korelasi negatif antara pola asuh otoriter dengan kematangan emosi sehingga 
dikategorikan hubungan yang cukup kuat [1]. Berdasarkan hasil perhitungan tersebut, maka hipotesis yang diajukan dalam penelitian ini menunjukkan ada hubungan negatif antara pola asuh otoriter dengan kematangan emosi diterima.

Selain itu, hasil analisis memperoleh koefisien determinasi $R$ Square $\left(\mathrm{R}^{2}\right)$ sebesar 0,324. Nilai ini memiliki arti pola asuh otoriter memberikan sumbangan 32,4 persen mempengaruhi kematangan emosi selebihnya 67,6 persen dipengaruhi oleh faktor lain, seperti kelekatan aman, jenis kelamin, usia, layanan bimbingan kelompok, pelatihan asertif, dan layanan penguasaan konten dengan teknik bermain (games). Hasil analisis sumbangan efektif dapat dilihat pada tabel 8.

Tabel 8.

Sumbangan Efektif

\begin{tabular}{|c|c|c|c|c|}
\hline Model & $\mathbf{R}$ & $\boldsymbol{R}$ Square & Adjusted R Square & Std. Error of the Estimate \\
\hline 1 & 0,569 & 0,324 & 0,317 & 8,657 \\
& & & & \\
\hline
\end{tabular}

\subsection{Pembahasan}

Hasil penelitian pada 98 siswa Sekolah Talitakum Medan yang menjadi subjek penelitian, diperoleh hasil bahwa ada hubungan antara pola asuh otoriter dengan kematangan emosi dengan koefisien korelasi sebesar $r=-0,569$ dan nilai $p=0.000$, artinya semakin tinggi pola asuh otoriter maka semakin rendah tingkat kematangan emosi, dan sebaliknya semakin rendah pola asuh otoriter maka semakin tinggi tingkat kematangan emosi.

Hasil penelitian ini sejalan dengan pendapat Santrock [11] menyatakan bahwa sisi negatif dari pola asuh otoriter atau otoritarian adalah membangun perasaan takut, cemas, tidak bahagia, tidak terbentuknya inisiatif dan juga ketidakmampuan membangun komunikasi dengan baik. Jika dikaitkan dengan karakteristik kematangan emosi menurut Walgito [14], maka ketiadaan inisiatif merujuk pada ketidakmampuan seseorang dalam merespon stimulus dengan cara berpikir yang baik, dan ketidakmampuan membangun komunikasi merujuk pada lemahnya kemampuan untuk memberikan tanggapan terhadap stimulus. Selain itu jika dikaitkan dengan kriteria kematangan emosi menurut Kusumawanta [6], maka seseorang yang takut, cemas dan tidak bahagia menunjukkan bahwa individu tersebut tidak mampu untuk menemukan kedamaian jiwa yang merupakan salah satu kriteria kematangan emosi. Berdasarkan penjelasan dari beberapa ahli di atas, dapat diketahui bahwa terdapat hubungan antara pola asuh otoriter dengan kematangan emosi.

Adapun hasil penelitian ini sejalan dengan penelitian yang dilakukan oleh Fellasari dan Lestari [4] pada siswa SMAN 2 Tambang Kabupaten Kampar. Diketahui bahwa orangtua yang menggunakan pola asuh otoriter lebih mengharapkan anak mereka mengikuti setiap perkataan mereka, sehingga remaja yang memperoleh pola asuh tersebut cenderung memiliki perilaku negatif kepada orang lain. Ini menunjukkan bahwa ada hubungan negatif antara pola asuh orang tua otoriter dengan kematangan emosi remaja dengan nilai koefisien regresi $\beta$ sebesar - 0,331 dengan Fhitung sebesar 16,656 pada taraf signifikansi sebesar 0,000, $(\mathrm{p}<0,05)$. Artinya semakin tinggi pola asuh otoriter, maka semakin rendah kematangan emosi. Sebaliknya semakin rendah pola asuh otoriter, maka semakin tinggi kematangan emosi.

Berdasarkan wawancara terhadap siswa yang memiliki kematangan emosional kategori sedang, dapat diungkapkan melalui karakteristik bahwa mereka mempunyai tanggung jawab yang baik. Para siswa sering terburu-buru mengumpulkan tugas atau pekerjaan rumah dikarenakan mereka mengerjakan tugas bila sudah merasa terdesak oleh waktu pengumpulan yang sudah dekat. Mereka sadar bahwa tugas adalah hal yang wajib dikerjakan namun di sisi lain juga suka menunda untuk menyelesaikan tugas tersebut. Kemudian, siswa dengan kategori kematangan emosional sedang dapat menerima baik keadaan dirinya. Para siswa merasa bahwa mereka bahagia dengan kehidupan mereka saat ini. Walaupun terkadang suka membandingkan diri dengan banyak orang dari media sosial, mereka tetap mengungkapkan bahwa mereka senang akan kehidupan mereka yang sekarang. 
Sejumlah 59 siswa produksi Sekolah Talitakum Medan menunjukkan kematangan emosi yang tinggi dengan persentase 60,20 persen terlihat dari karakteristik tidak bersifat impulsif, dapat mengontrol diri dengan baik. Selain itu, banyak siswa yang menyatakan bahwa mereka memiliki hubungan pertemanan yang baik. Jarang terjadi konflik yang berarti antar siswa. Mereka mengaku akrab satu sama lain, baik antar sesama kelas, senior maupun junior.

Melalui penelitian ini juga diperoleh bahwa terdapat 38 siswa dengan persentase 38,78 persen. Selebihnya, 60 siswa dikategorikan memiliki pola asuh otoriter sedang dengan persentase sebesar 61,22 persen dan tidak ada siswa yang memiliki pola asuh otoriter yang rendah. Rata-rata siswa Sekolah Talitakum Medan memiliki pola asuh otoriter yang sedang.

Berdasarkan hasil observasi dan wawancara terhadap siswa yang menunjukkan pola asuh otoriter sedang, dapat diungkapkan melalui dimensi verbal hostility. Sebagian siswa mengaku memiliki orang tua yang nada bicaranya keras dan lugas. Jika sedang marah, para siswa mengungkapkan bahwa orang tua mereka bisa saja mengucapkan kata-kata kasar dan meneriaki mereka. Makian kasar tersebut dilontarkan bila mereka tidak melakukan apa yang diinginkan oleh orang tua mereka. Selain itu, juga tampak dimensi corporal punishment. Sebagian besar siswa mengaku sering menerima hukuman berupa kekerasan secara fisik dari orang tua mereka bila melakukan kesalahan. Mulai dari ditampar, dicubit, ataupun dijewer oleh orang tua. Mereka mengungkapkan hal seperti itu merupakan hal yang biasa terjadi. Sejak kecil mereka telah mendapatkan perlakuan tersebut bila melakukan tindakan yang dianggap menyalahi aturan orang tua.

Pada siswa yang mendapat pola asuh otoriter yang tinggi, mereka mengalami dimensi directiveness. Siswa-siswa tersebut sangat patuh pada segala perintah dari orang tua. Sejak dini, mereka telah diminta harus memilih jurusan kuliah sesuai dengan keinginan orang tua. Ketika dilakukan wawancara terhadap para siswa, mereka mengungkapkan bahwa mereka jarang dapat mengekspresikan diri mereka sendiri, akibat harus memenuhi ekspektasi orang tua akan diri mereka. Selain itu mereka mengaku sering merasa dikekang oleh orang tua mereka, seperti harus bersikap manis pada seluruh keluarga walaupun mereka sedang tidak berada dalam suasana hati yang baik.

\section{Kesimpulan}

Berdasarkan hasil penelitian yang telah diperoleh, maka dapat diambil kesimpulan sebagai berikut: Ada hubungan negatif antara pola asuh otoriter dengan kematangan emosional pada siswa SMP Talitakum Medan dengan korelasi Product Moment (r) sebesar - 0,569 dan p sebesar 0,000 ( $p<0,05)$, artinya semakin tinggi pola asuh otoriter, maka semakin rendah tingkat kematangan emosi, dan sebaliknya semakin rendah pola asuh otoriter, maka semakin tinggi tingkat kematangan emosional. Nilai sumbangan efektif yang diberikan variabel pola asuh otoriter terhadap variabel kematangan emosi adalah sebesar 32,4 persen, selebihnya 67,6 persen dipengaruhi oleh faktor lain, seperti kelekatan aman, jenis kelamin, usia, layanan bimbingan kelompok, pelatihan asertif, dan layanan penguasaan konten dengan teknik bermain (games).

\section{Daftar Rujukan}

[1] Arikunto, S., Prosedur Penelitian Suatu Pendekatan Praktik. Jakarta: Rineka Cipta, 2013.

[2] Azwar, S., Penyusunan Skala Psikologi. Yogyakarta: Pustaka Belajar, 2006.

[3] Berns, R. M., Child, Family, School, Community: Sosializations and Support 9th Edition. Wadsworth: Cengange Learning. $\quad$ E-book, $2012 . \quad$ [online]. Available: https://www.goodreads.com/book/show/12430007-child-family-school-community. [Diakses: 08 Februari 2020]

[4] Fellasari, F., \& Lestari, Y. I., Hubungan Antara Pola Asuh Orangtua dengan Kematangan Emosi Remaja. Jurnal Psikologi, Vol. 12, No. 2, Desember 2016. [online]. Available: http://ejournal.uinsuska.ac.id/index.php/psikologi/article/download/3234/2034. [Diakses: 08 Februari 2020]

[5] Hurlock, E. B., Psikologi Perkembangan: Suatu Pendekatan Sepanjang Rentang Kehidupan. Jakarta: Erlangga, 2011.

[6] Kusumawanta, D.G.B., Imam Diambang Batas. Yogykarta: Kanisius, 2009. 
[7] Lumenta, N., Wungouw, H. I. S., \& Karundeng, M., Hubungan Pola Asuh Orang Tua dengan Kematangan Emosi Remaja di SMAN 1 Sinonsayang. E-Journal Keperawatan (e-Kp), Vol. 7, No. 1, Mei 2019. [online]. Available: https://ejournal.unsrat.ac.id/index.php/jkp/article/download/24344/24013. [Diakses: 08 Februari 2020]

[8] Nazir, M., Metode Penelitian. Jakarta: Penerbit Ghalia Indonesia, 2003.

[9] Noviata, A., Pengaruh Pola Asuh Otoriter Terhadap Kematangan Emosi Pada Remaja SMA. Jurnal Ilmiah Psikologi, Vol. 9, No. 1, Juni 2016. [online]. Available: https://media.neliti.com/media/publications/100459-ID-pengaruh-pola-asuh-otoriter-terhadap-kem.pdf. [Diakses: 06 Februari 2019]

[10] Robinson, C., et al., Authoritative, Authoritarian, and Permissive Parenting Practices: Development of A New Measure. Psychological Reports, Vol. 77, Issue 3, 1995. [online]. Available: https://journals.sagepub.com/doi/10.2466/pr0.1995.77.3.819. [Diakses: 08 Februari 2020]

[11] Santrock, J. W., Perkembangan Anak. Jakarta: Erlangga, 2014.

[12] Sudarsono, Kamus Filsafat dan Psikologi. Jakarta: Rineka Cipta, 1993.

[13] Sugiyono, Metode Penelitian Kuantitatif Kualitatif dan R\&D. Bandung: Alfabeta, 2010.

[14] Walgito, B., Pengantar Psikologi Umum. Jakarta: Andi, 2004.

[15] Medan.tribunnews.com, Gagah Saat Tawuran Remaja Ini Tak Berkutik dan Menangis Saat Dibawa ke Kantor Polisi, 2020. [online]. Available: https://medan.tribunnews.com/2020/01/11/gagah-saat-tawuranremaja-ini-tak-berkutik-dan-menangis-saat-dibawa-ke-kantor-polisi?page=3 [Diakses: 10 Februari 2020] 